\title{
LETTERS
}

\section{Canada Health Act has bite}

CMAJ's Nov. 1 editorial ${ }^{1}$ contains errors and omissions that deserve correction. The Canada Health Act already has "bite" by virtue of the federal government's ability to withhold transfer payments from provinces that violate its principles.

The next time CMAJ opines on matters before the courts it should first obtain legal verification of the facts. Nothing in the current constitutional challenge in British Columbia challenges the act. The act does not ban private insurance for medically necessary services. The ban on user fees and extra-billing applies only to the publicly funded and insured health systems that exist in Canada. Four provinces permit private insurance for socalled medically necessary services, all allow private insurance for necessary drugs, dentistry, physiotherapy, braces and prosthetics, ambulances, etc. I suspect that CMAJ editors have such private "two-tier" insurance, which almost a third of Canadians don't have. This disparity in health coverage is unequivocal evidence of inequity in our system.

Sibbald and Stanbrook's reference to a debate taking place in a judicial hearing is also wrong.

CMAJ's selective and biased references cite op-ed pieces that contain erroneous statements on public and private financing and insurance. Those errors will be proven at trial. One quoted source is a government paid supporter and witness involved in the current litigation. Another is spokesperson for a trade union-funded group and an opposing intervenor in the trial. CMAJ's editorial inappropriately pre-judges evidence that will be heard at trial, which will show there was no extra billing and no double billing by Cambie Surgery Centre.

Our clinics voluntarily submitted to an audit after a judicial rejection of an injunction, requested by government, to conduct the audit. The only physician assigned to the audit team distanced himself from remarks of the audit report.
To reference the Ontario Health Coalition (another trade union-funded supporter of the groups opposing us) as a data source is equally without merit. Why did CMAJ not consider citing one of numerous reports within Canada that has shown that the private sector is more cost effective and safer than the public sector? I sense bias.

The amount Sibbald and Stanbrook refer to as being "docked" by the federal government (\$241637) was not based on our clinic's activities and the one-month's billings they refer to was actually over several years. In any case, that amount pales in comparison with the $\$ 300$ million that $B C$ private clinics save the public health system each year by removing over 60000 patients from public hospitals. The reference to equity ignores the fact that the Commonwealth Fund, as quoted by Federal Health Minister Jane Philpott, and reported in CMAJ, ranks Canada last in access, close to last in equity and near the top in cost of 11 developed countries. ${ }^{2}$

Although I appreciate that editorial independence allows CMAJ editors to opine on matters that are in conflict with the CMA, I remind CMAJ and its readers that it is CMA policy that "When access to timely care cannot be provided in the publicly funded system, Canadians should be able to use private health insurance to reimburse the cost of care obtained in the private sector." This lawsuit is about enacting CMA policy into law!

I also remind CMAJ that the Chaoulli decision, which CMAJ criticizes, was supported in a CMA-Ipsos Reid poll by over $80 \%$ of Canadian doctors, and over $60 \%$ of the public (www.lop.parl.gc.ca/Content/LOP/ ResearchPublications/prb0531-e.htm).

Sibbald and Stanbrook quote flawed foreign statistics from Kreindler, ${ }^{3}$ rather than Canadian governments' own data reported in 2012. Saskatchewan Health compared the cost of 34 procedures in private clinics with public hospitals, and showed that in all cases the clinics were less expensive, and in some cases, were half the cost. Overall, the total cost in the clinics was $26 \%$ less than in hospitals. ${ }^{4}$ In 2012, Alberta data showed that it cost $\$ 1539$ less per case to perform joint replacements in a private centre.

Both federal minister Philpott, and our provincial minister Terry Lake, have recently (citing the Commonwealth Fund) acknowledged the poor ranking of our health system. The goal of our litigation is to achieve a health system in which every Canadian receives timely access in a public system that ranks with the best in the world. We will prove that all of the top-ranked systems are based on hybrid models.

The CMAJ editorial team must be reminded of the importance of factchecking. It should display objectivity rather than bias, especially when active litigation is its subject. Most of the editorial content was gathered from false assertions that we have never previously bothered to refute. The reasons for that are twofold. First, we know the true facts will be determined at trial. Second, because the particular forums in which they were published were of relatively ill repute, and/or impervious to fact-checking. Perhaps naively, I expected higher standards from our own journal.

\section{Brian Day MRCP}

Medical Director, Cambie Surgery Centre, Vancouver, BC, and CMA Past-President, 2007-2008

Cite as: CMAJ 2017 January 9;189:E30. doi: $10.1503 / \mathrm{cmaj} .732494$

\section{References}

1. Sibbald B, Stanbrook MB. Canada Health Act needs bite CMAJ 2016;188:1133.

2. Rich P. Canada ranks second last in comparison of health systems. Ottawa: CMA; 2014. Available www.cma.ca/En/Pages/canada-ranks-secondlast.aspx (accessed 2016 Dec. 19).

3. Kreindler SA. Policy strategies to reduce waits for elective care: a synthesis of international evidence. BrMed Bull 2010; 95:7-32.

4. Saskatchewan surgical initiative data. Saskatoon: Saskatchewan Health; 2012.

Conflict of interest: Medical Director, Cambie Surgery Centre, Vancouver, BC 